\title{
In vitro antioxidant and anticancer activity of methanolic extract of Trachyspermumammiseed on human oral cancer (KB) cell line.
}

\author{
Mohanprasanth Aruchamy ${ }^{2}$,and Dr. Pradeepa Duraisamy ${ }^{1^{*}}$ \\ 1- Assistant Professor, 2- Postgraduate student \\ PG and research Department of Biochemistry, \\ Dr. N.G.P. Arts and Science College (Autonomous), Coimbatore - 641048.
}

*Author for correspondence (Email: pradeepaduraisamy@gmail.com)

\begin{abstract}
The present study was to determine the phytochemical constituents, antioxidant, and anticancer potential of methanolic extract from the seeds of Trachyspermumammi on KB, human oral cancer cell line using in vitro assay system. The seeds of the T. ammi was extracted with methanol. Phytochemical screening was done using standardqualitative biochemical tests. Antioxidant activity of the T. ammiextract were determined by using phosphomolybdenum assay.MTT assay was used to estimate the antiproliferative activity of the extractagainst human oral cancer (KB) cell line. The apoptotic inducing ability of the extract was investigated by intracellular ROS analysis, antioxidant enzyme levels (SOD, CAT, GPx and GSH), EtBr/AO staining and TBARS analysis.The qualitative phytochemical analysis revealed the presence of different secondary metabolite. The phytochemical content present in the methanolic extract possessed high antioxidant capacity with transition metal reduction in phosphomolybdate assay. The methanol seed extract was found to be cytotoxic in vitro to (KB) oral cancer cell lines with $\mathrm{IC}_{50}$ value $125 \mu \mathrm{g} / \mathrm{ml}$.Significantly, the T. ammi seed extract showed a broad-spectrum anticancer activity through promoting ROS generation via modulating apoptosis induction in KBoral cancer cells. From the results, it can be concluded that T. ammiseed extract was a promising antioxidant and anticancer agent for KB human oral cancer cell line. The resultsfigure the sufficient scientific backgrounds to isolate and purify the bioactive compoundsin future for further applications.
\end{abstract}

Keywords:Trachyspermumammi, oral cancer, antioxidant, anticancer, ROS.

\section{Introduction:}

Oral cancer is a foremost problem in public health, and it scored as $13^{\text {th }}$ rank among all other cancer [1]and one of the most predominant carcinomas symbolizing 10 most common causes of death [2]. The attributes of present lifestyle in the developing countries are said to be reason for major health problems of today [3]. 90\% oral cancer is a malignant neoplasia, histologically originated from a squamous cell in the dental area which is lips, tongue, gingiva and any part of mouth $[4,5]$. Theetiological factors of oral cancer can be internal or external.External factors are tobacco, chemicals, radiation and infectious organisms and the internal factors include inherited mutations, hormones and immune status causing cancers [6].

In recent years, the metastatic stage of oral cancer was treated bysurgery, radiotherapy, and followed by chemotherapy treatment for maintenance. But unfortunately, the body's cells are also getting damaged and destroyed by these therapies [7]. The antimetabolites, DNA-interactive agents, anti-tubulin agents, hormones and molecular targeting agents are the existing chief chemotherapeutic agents [8]. Recurrence of cancer, drug resistance, and toxic effects on non-targeted tissues that can restrain the use of anticancer drugs are the major disadvantages of chemotherapy which weaken the person's life quality. These problems can be overcome by searching for new anticancer agents with better efficacy and lesser side effects[9]. In the new therapeutic approaches, the most promising one is naturally acquired agents with known anticarcinogenic effects [10-12].

Plant derived drugs havepotential possibility to cure various disease without any toxicity to normal cell. Altering cell cycle control, apoptosis evasion, angiogenesis and metastases are the properties of phytochemicals that attract scientists towards this research [13]. The use of complementary alternative medicines has dramatically 
increased in India along with USA, in the last 2 decades [14]. Approximately 60\% of anticancer agents are derived from medicinal plants and other natural resources; however, there are still several plants that have an anticancer potential, but they have not yet been fully investigated[15]. The presentrising interest in dietary plants has directed to renewed attention in Trachyspermumammidue to its several active compounds.

Trachyspermumammi, belongs to the family of Apiacea is rich in secondary metabolites and have good antioxidant properties. T. ammi leaves already have anti-spasmodic, stimulatory, and carminative properties [16]. Seed of T. ammi are used for food flavoring purpose and as preservative. T. ammi seeds show anti-inflammatory, anti-microbial, immunomodulatory, anti-filarial, hypolipidemic, anthelmintic, gastro-protective and nematicidal activity based on folktale practices and research studies [17].The plant has more polyphenols, which act as a prooxidant against cancer cells by inducingoxidative DNA damage in the presence of transition metal such as copper ions, results inapoptosis of cancer cells [18].Nevertheless, this plant seed has not been studied for anticancer activity on oral cancer and there are very few available studies on antioxidant properties of this seeds. Hence, an attempt was made to use this herbal plant seeds to verify the effectiveness against oral cancer cell lines. The current study was aimed to evaluate preliminary phytochemical, total antioxidant capacity, and in vitro anticancer potential activities against KB human oral cancer cell lines.

\section{Materials and Methods:}

\subsection{Collection of plant material}

The seeds of T. ammi were purchased from the local market of Coimbatore, Tamil Nadu.The seed material was washed with water, air dried, and then blended to a fine powder. The powder was stored in airtight containers at $4{ }^{\circ} \mathrm{C}$ for further use.

\subsection{Human oral cancer cell line (KB Cell line):}

Human oral carcinoma (KB) cell lines were procured fromNCCS, Pune, India. This cell line was grown in complete culture medium consisting of high glucose, DMEM supplemented with $10 \%$ fetal bovine serum and $1 \times$ penicillin at $37^{\circ} \mathrm{C}$ in a humidified atmosphere at $5 \% \mathrm{CO}_{2}$ and trypsin.

\subsection{Preparation of Extarct}

A sample of $50 \mathrm{~g}$ of $T$. ammi seed powder was extracted with $250 \mathrm{~mL}$ ofmethanol using a Soxhlet extractor. The extract was concentrated by a rotary vacuum evaporator and the left-over solvent was evaporated to dryness using a water bath.The extracted crude samples were kept in airtight glass vials and stored at $4{ }^{\circ} \mathrm{C}$ until use.

\subsection{Phytochemical screening}

The crude methanolic extract of T. ammi seed was qualitatively screened for different phytochemical constituents namely carbohydrates, proteins, amino acid, alkaloids, phenols, phytosterols, tannins, flavonoids, coumarin, glycosides, terpenoids, saponin and thiols by following the procedure ofHarbone, (1973) and Wagner and Elmadfa, (2003) [19,20].

\subsection{Evaluation of in vitro antioxidant capacity}

The total antioxidant activity was estimated by Phosphomolybdenum (PM) assay using standard procedure ofPrieto et al. (1999) [21]. Methanol extract of seeds of T. ammi in different concentration ranging from $20 \mu \mathrm{g}$ to $100 \mu \mathrm{g}$ were added to each test tube individually containing $3 \mathrm{~mL}$ of distilled water and $1 \mathrm{~mL}$ of molybdate reagent solution. These tubes were kept incubated at $95{ }^{\circ} \mathrm{C}$ for 90 minutes. After incubation, they are kept at room temperature for 20-30 minutes and the absorbance was measured at $695 \mathrm{~nm}$. Ascorbic acid was used as the reference standard.

\subsection{Determination of Anticancer Effect of T.ammi seed methanolic extract:}

\subsubsection{Cytotoxicity assay (MTT)}

The cytotoxic activity of crude extract of $T$. ammi seed against human oral cancer cell line (KB cells) was determined by MTT assay [22]. The crude extract was dissolved in dimethyl sulfoxide (DMSO) and diluted appropriately by using DMEM medium. Cultured KB cell $\left(1 \times 10^{6} \mathrm{cell} / \mathrm{s} / \mathrm{ml}\right)$ was taken into a 96 well plate. 
Absorbance was measured in a microplate reader at $540 \mathrm{~nm}$. Images captured under microscope. Percentage cytotoxicity was calculated as follows:

$\%$ Viability $=$

Total number of viable cell

$\times 100$

Total number of viable and nonviable cells

\subsubsection{Dichloro-dihydro-fluorescein diacetate (DCFH-DA) assay for oxidative stress assessment of extract-treated cells}

Dichlorodihydrofluorescein diacetate (DCFH-DA) is a nonpolar dye, metamorphose into the polar derivative DCFH by cellular esterases that are nonfluorescent but transmute to highly fluorescent DCF when oxidized by intracellular ROS and other peroxides [23]. Accumulation of DCF in cells could also be measured by an increase in fluorescence at $530 \mathrm{~nm}$ when the sample is excited at $485 \mathrm{~nm}$. The results were expressed as percentage fluorescence intensities.

\subsubsection{Evaluation of apoptotic morphological changes by Acridine orange(AO) / Ethidium bromide (EtBr) staining [24]}

KB cells were seeded in 6-well plate $\left(1 \times 10^{6} /\right.$ well $)$ and Methanolic seed extract of $T$. ammi treated KB cells incubated in $\mathrm{CO}_{2}$ incubator for $24 \mathrm{~h}$. The cells were fixed with methanol: glacial acetic acid (3:1) for 30 min at room temperature. The cells were washed in PBS and stained with 1:1 ratio of AO/EtBr. Stained cells were immediately washed again with PBS and viewed under a fluorescence microscope. The number of cells showing features of apoptosis was counted as a function of the total number of cells present in the field.

\subsubsection{TBARS Assay}

The measurement of Thiobarbituric acid reactive substances (TBARS) was carried out as an index of lipid peroxidation and measured in terms of malondialdehyde (MDA) content by the method of Niehaus and Samuelsson, (1968) [25]. MDA and other TBARS were measured by their reactivity with Thiobarbituric acid in an acidic condition to generate pink coloured chromophore which was read at $535 \mathrm{~nm}$.

\subsubsection{SOD, CAT, GPX and GSH activities assay}

The supernatant obtained from control (without treatment) and treated KB cell line with T. ammi seed methanolic extract after centrifuging the trypsinized cells was used for the estimation of SOD, CAT, GPX and GSH activities. Superoxide dismutase (SOD) [26]activity was measured the dismutation of superoxide radicals generated, Catalase (CAT) [27]activity was measured for the detoxification of hydrogen peroxide,Glutathione peroxidase (GPx) [28]activity was measured with glutathione reductase (GR) reduced state by NADPHand Reduced glutathione (GSH) [29] activity by measuring the increase in the concentration of the conjugation product of GSH.

\subsection{Statistical Analysis}

All the values were expressed as means of six $(n=3)$ determinations. The data were statistically analyzed using one-way ANOVA on SPSS and the group means were compared by Duncan's Multiple Range Test (DMRT). The results were considered statistically significant if the $P<0.05$ levels.

\section{RESULTS AND DISCUSSION}

\subsection{Phytochemical screening:}

The preliminary phytochemical analysis of methanolic seed extract of T.ammi helps us to identify the available bioactive compounds, which showed presence of diversity of phytochemical constituents.It showed positive results for the presence ofamino acid, alkaloids, phenols, flavonoids, tannins, coumarin, glycosides, terpenoids, saponin and steroids and absence of carbohydrates, proteins and thiols (Table 1). 
Table 1: Phytochemical screening

\begin{tabular}{|l|c|}
\hline Tests & $\begin{array}{l}\text { Methanolic seed extract of } \\
\text { Trachyspermumammi }\end{array}$ \\
\hline Amino Acid & + \\
\hline A) Ninhydrin Test & + \\
\hline Alkaloids & + \\
\hline A) Wagner's Test & + \\
\hline B) Mayer's Test & + \\
\hline Phenols & + \\
\hline A) Lead acetate & + \\
\hline Flavonoids & + \\
\hline A) Ferric Chloride Test & \\
\hline Coumarin & + \\
\hline A) Alcoholic Sodium Hydroxide Test & \\
\hline Tannins & + \\
\hline A) Ferric chloride Test & \\
\hline Terpenoids & + \\
\hline A) Salkowski's Test & \\
\hline Steriods & + \\
\hline A) Libermann - Burchard's Test & \\
\hline Saponins & \\
\hline A) Foam Test & \\
\hline Cardiac Glycosides & \\
\hline A) Keller - Kiliani's Test & \\
\hline Thiols & \\
\hline A) Sodium Nitroprusside Test & \\
\hline \multicolumn{2}{|l|}{} \\
\hline
\end{tabular}

(+) present compounds: (-) absent compounds in methanolic extract of T.ammi seeds.

\subsection{In vitro antioxidant capacity:}

Antioxidants cause protective effect by neutralizing free radicals, which are toxic byproducts of natural cell metabolism. The human body has several mechanisms to counteract oxidative stress by producing antioxidants, which are either naturally produced in situ or externally supplied through foods and/or supplements. These antioxidants act as free radical scavengers by preventing and repairing damages caused by ROS and therefore can enhance the immune defense and lower the risk of cancer and degenerative diseases [30]. In the current study, crude methanol extract of T. ammi seed was subjected to PM assay along with standard ascorbic acid.It aidsin assessing the reduction rate among the antioxidant and molybdenum ligand. Methanol extract showed the highest activitywhen the concentration increases to $100 \mu \mathrm{g}$ (Figure 1). The resultindicates that the antioxidant activity increases from 20 $\mu \mathrm{g}$ to $100 \mu \mathrm{g}$ in a concentration dependent manner.Aftab et al.(1995) reported that $T$. ammi methanol extract possesses strong antioxidant activity against DPPH and could be used as natural antioxidants in food or pharmaceutical industry [31]. 


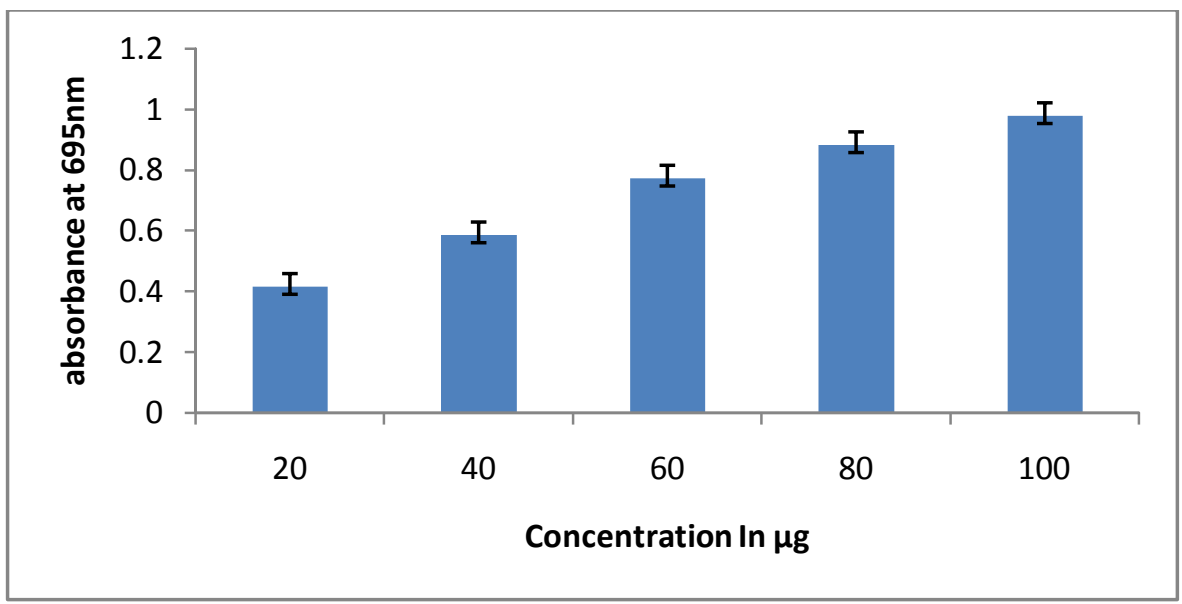

Figure 1: In vitro antioxidant capacity

Values are given as means \pm SD of three experiments in each group (ANOVA and followed by DMRT). Bars not sharing a common superscript differ significantly at $\mathrm{P}<0.05$.

\subsection{Determination of Anticancer Effect of T.ammi seed methanolic extract:}

\subsubsection{Cytotoxicityassay:}

MTT assay is a proven in vitro system for evaluating cytotoxicity against cancer cell lines.The cytotoxic effect of methanolic seed extract of T.ammion human oral cancer cell line by MTT assay.The experimental results demonstrate that the extract inhibited cell proliferation in a dose dependent manner. The $\mathrm{IC}_{50}$ values of the extract against cancer cells were calculated and it is found to be $125 \mu \mathrm{g} / \mathrm{ml}$ (Figure 2). The methanolic extract of T. ammi seeds significantly inhibits the proliferation of selected human oral cancer cells (KB).

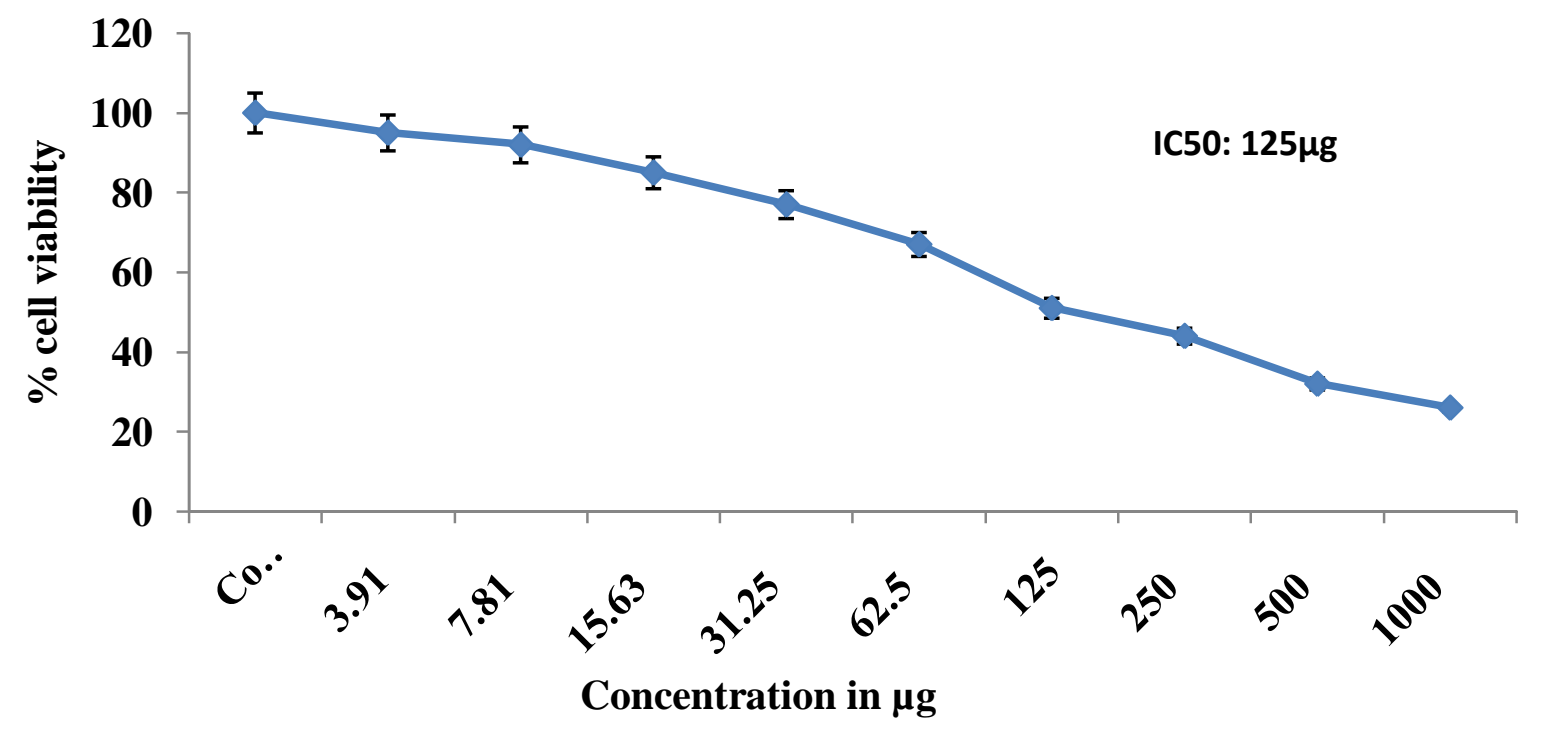

Figure 2: Cytotoxic effect:

Values are given as means \pm SD of three experiments in each group (ANOVA and followed by DMRT). Bars not sharing a common superscript differ significantly at $\mathrm{P}<0.05$. 


\subsubsection{Measurement of T. ammi seed methanolic extract induced ROS levels:}

Intracellular ROS is extremely produced in the treated cell compared with control cells during 24hrs incubation. Increased ROS level is measured by DCF fluorescents method. Level of ROS generation in control and treated cells illustrate in Figure 3i\&3ii.T. ammiseed methanolic extract treatment significantly increased ROS level in KB cells with increased extract concentration. Among all the doses tested, $20 \mu \mathrm{g} / \mathrm{ml}$ of methanolic extract of T. ammi showed maximum generation of ROS $85 \%$.

i)
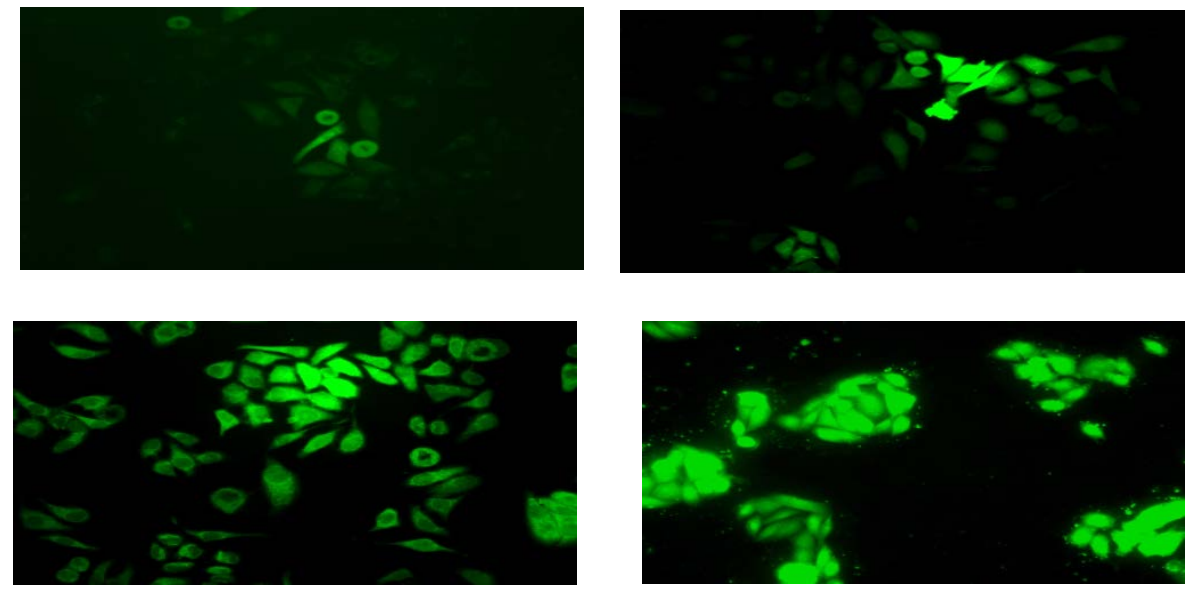

ii)

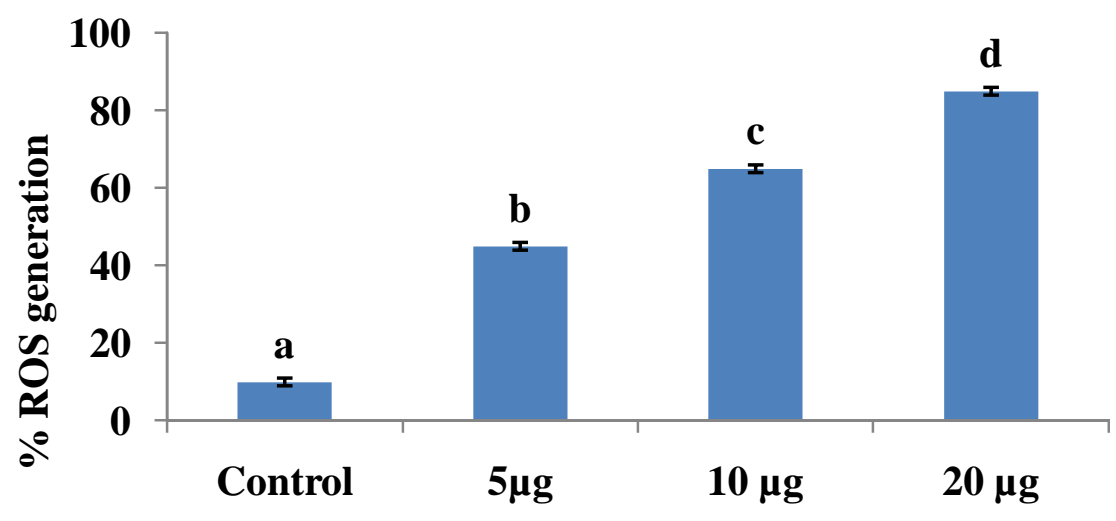

Figure 3: Measurement of T. ammi seed methanolic extract induced ROS levels:

Figure 3i: Untreated KB cells show weak fluorescence DCF Methanolic seed extract of Trachyspermumammi. Treated KB cell shows increased ROS generation was indicate deep DCF fluorescence intensity. ii) Spectrofluorometric readings of DCF fluorescence in control and Methanolic seed extract of Trachyspermumammi treated cells. Values are given as means \pm SD of three experiments in each group (ANOVA and followed by DMRT). Values not sharing a common superscript differ significantly at $\mathrm{P}<0.05$.

\subsubsection{Evaluation of apoptosis induced by methanolic extract of T. ammi using AO/EtBr Staining:}

The apoptogenic feature of the methanolic extract of $T$. ammiseed was investigated by observing the morphological changes in KB cells (Figure 4i \&4ii). Untreated (DMSO control) cells emitted green fluorescence indicating normal nucleus with intact cell membrane. The T. ammi methanolic extract treated cells changed green fluorescence into reddish orange indicating the loss of membrane integrity, cellular shrinkage, membrane blebbing, and typical 
nuclear fragmentation which might be due to apoptosis with increase in concentration. The present study showed 92, 75 and $36 \%$ apoptotic cells in 20,10 , and $5 \mu \mathrm{g} / \mathrm{ml}$ treated cells, respectively.

i)

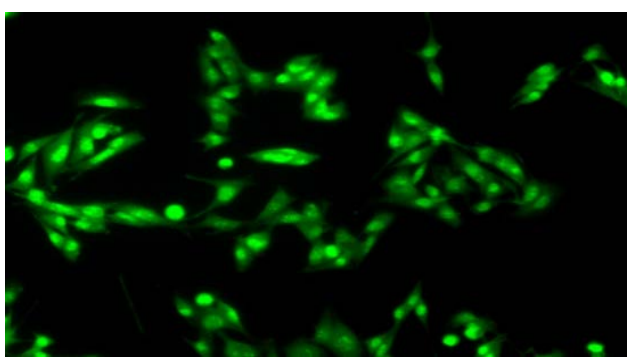

Controlcontrol

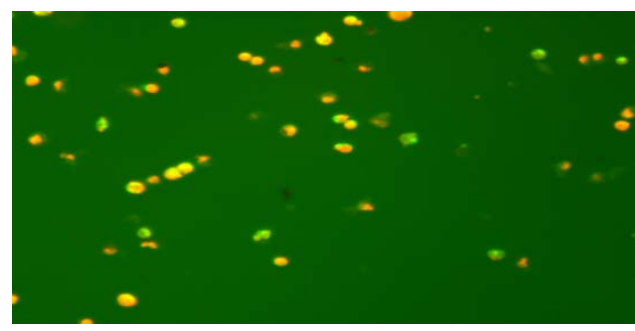

$10 \mu \mathrm{g}$ conc10 $\mu \mathrm{g}$ conc

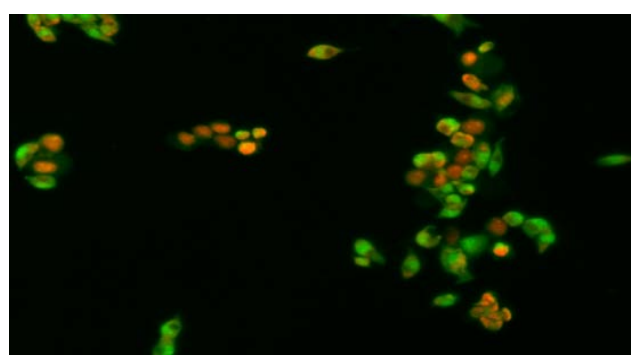

$5 \mu \mathrm{g}$ conc5 $\mu \mathrm{g}$ conc

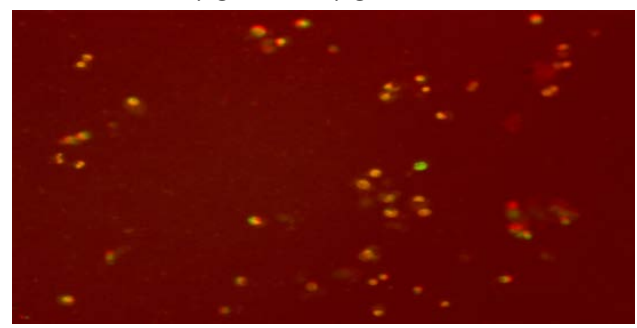

$20 \mu \mathrm{g}$ conc20 $\mu \mathrm{g}$ conc

ii)

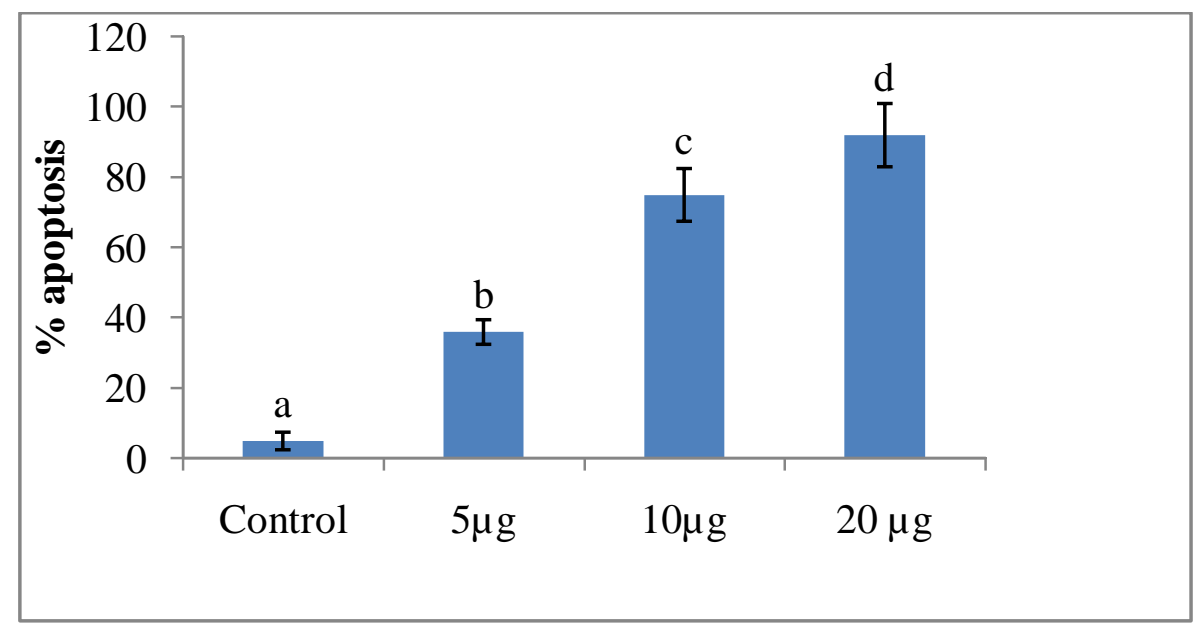

Figure 4:Evaluation of apoptosis induced by methanolic extract of T. ammi using Acridine Orange/Ethidium Bromide Staining

Figure 4i: shows effect of Methanolic seed extract of Trachyspermumammi on apoptotic morphological changes in $\mathrm{KB}$ cells by $\mathrm{EtBr} / \mathrm{AO}$ staining. ii) Bar diagram represents \% of apoptotic morphological changes. Values are given as means \pm SD of three experiments in each group (ANOVA and followed by DMRT). Values not sharing a common superscript differ significantly at $\mathrm{P}<0.05$ vs. control.

\subsubsection{TBARS Assay}

The study observed that the methanolic extract of T. ammi seed in KB cells induce the lipid peroxidation (Figure 5). It indicates the oxidative degradation of lipids in cells membranes, resulting in cell damage. Among all the concentrations (5, 10 and $20 \mu \mathrm{g} / \mathrm{ml}$ ) tested, $20 \mu \mathrm{g} / \mathrm{ml}$ methanolic extract showed maximum levels of TBARS (2.15 
$\mu \mathrm{Mol} / \mathrm{mg}$ protein).The oxidation of cell membrane lipids liberates the cytotoxic byproduct Malondialdehyde (MDA) rapidly interacts with cellular protein and DNA molecules whichin turn cause cell death. The increase in MDA level is in dose dependent manner during the 24 hours incubation period.

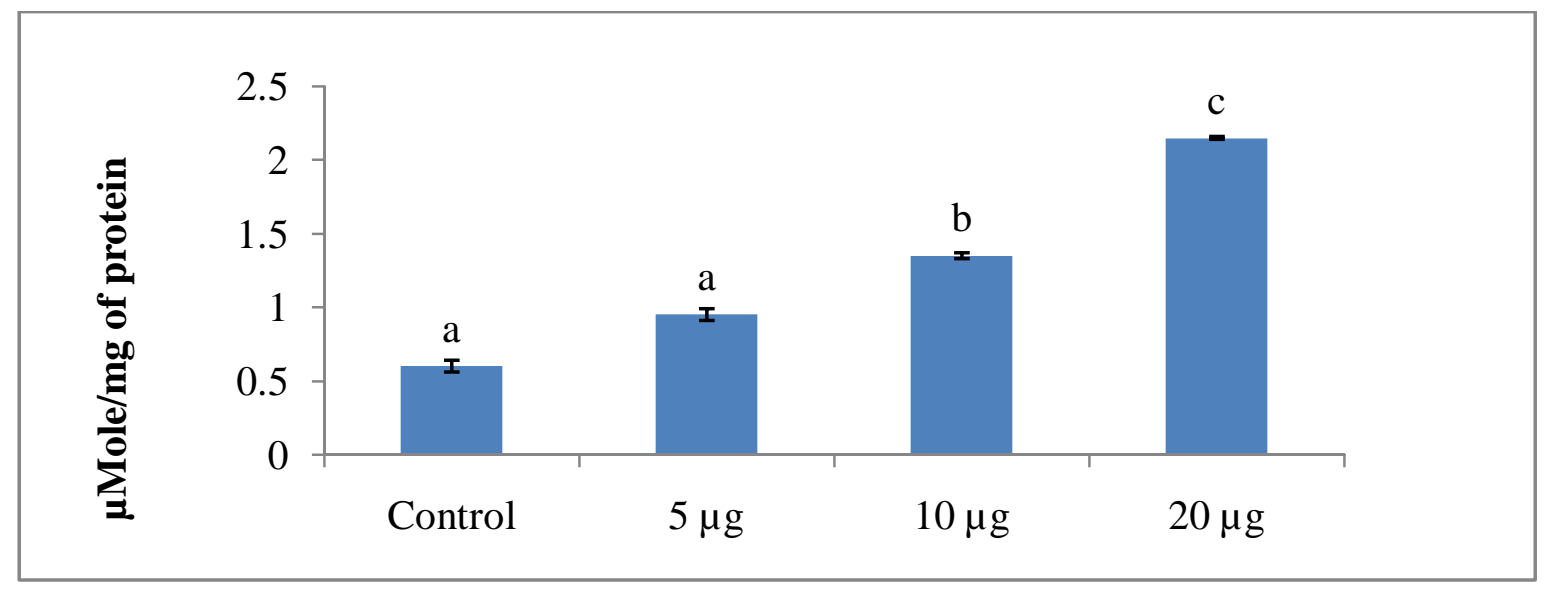

Figure 5:TBARS Assay

Figure 5: shows the results of lipid peroxidation. Values are given as means \pm SD of three experiments in each group (ANOVA and followed by DMRT). Values not sharing a common superscript differ significantly at $\mathrm{P}<0.05$ vs. control.

\subsubsection{Changes in the levels of antioxidant enzymes and GSH level:}

Methanolic extract of $T$. ammi seeds (5, 10 and $20 \mu \mathrm{g} / \mathrm{ml})$ treatment significantly decreased the activities of SOD, CAT, GPx and decreased GSH levels in KB cells. Among all the doses tested, $20 \mu \mathrm{g} / \mathrm{ml}$ of methanolic extract significantly decreased enzymatic activities and GSH level when compared with other doses (Figure 6i \& 6ii).The depletion of GSH causes the mitochondrial depolarization which triggers the cellular intrinsic apoptosis pathway[32]. This may be reason for increase in intracellular ROS level which leads to DNA damage followed by apoptosis in human oral cancer (KB cell line).

i) The levels of antioxidant enzymes

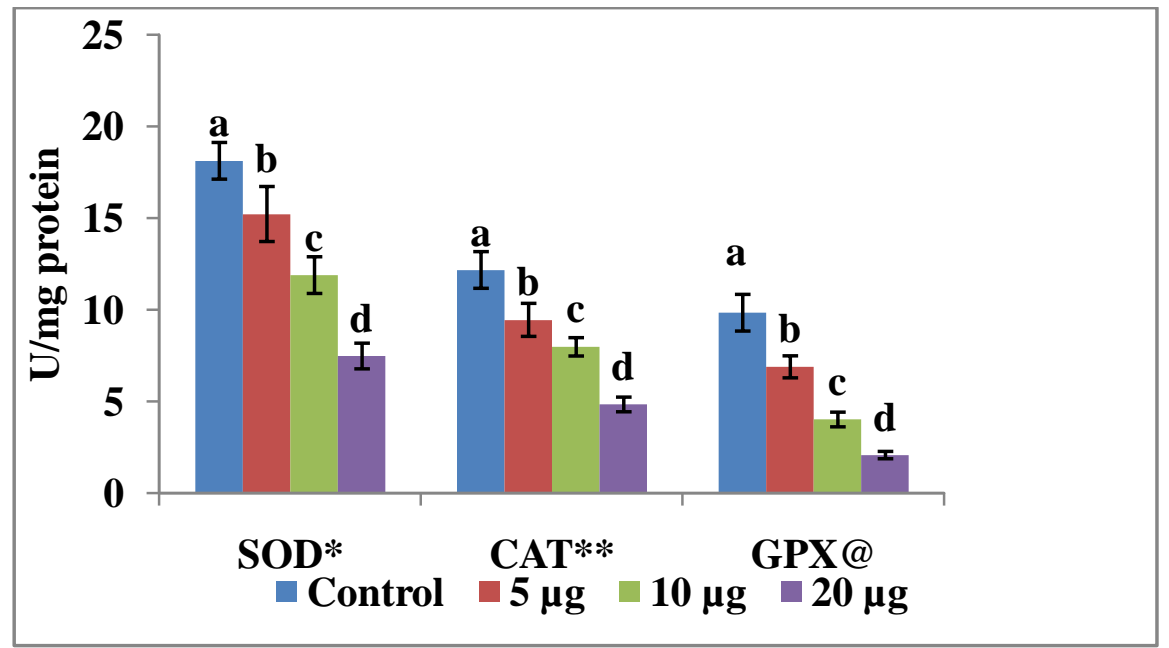




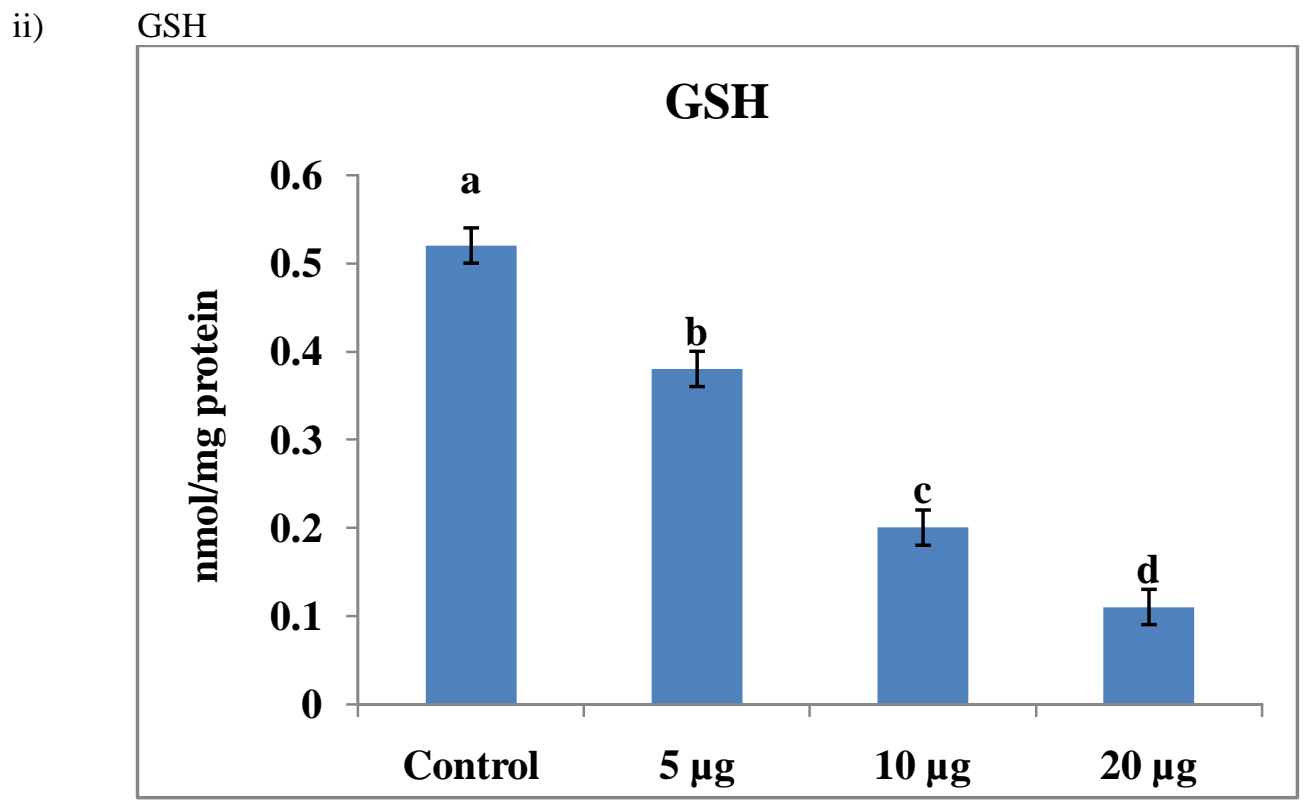

Figure 6: Evaluate Antioxidant Enzymes Level

Figure 6: i) shows the activities of antioxidant enzymes. ii) Level of reduced glutathione. Values are given as means \pm SD of three experiments in each group (ANOVA and followed by DMRT). Values not sharing a common superscript differ significantly at $\mathrm{P}<0.05$ vs. control.

\section{Conclusion:}

The results of the present study indicate that the methanolic extract of $T$. ammi seeds has the presence of major phytochemicals and antioxidant capacity. Our findings clearly demonstrated that the methanolic extract of T. ammi exhibited the significant cytotoxic and apoptotic inducing effects. The results are found to be promising for the use in chemopreventive and chemotherapeutic strategies and are further required to elucidate the detailed molecular mechanism regulated by the bioactive compounds present in the T. ammi seed methanolic extract to combat oral cancer. Further investigations are necessary to validate in in-vivo models also to claim its therapeutic effect against oral cancer.

\section{Conflicts of interest:}

The authors declare that they have no competing interests.

\section{Acknowledgement:}

The authors acknowledge the use of instrumentation and infrastructure facilities provided by DST-FIST and DBTStar college scheme, Ministry of science and Technology, Govt. of India for the successful completion of project dissertation. We thank the host institution Dr. N.G.P. Arts and Science College, Management for rendering all the facilities and support. Communication number: DrNGPASC 2020-21 BS080.

\section{Reference:}

1. D'Souza W, Kumar A. microRNAs in oral cancer: Moving from bench to bed as next generation medicine. Oral Oncol. 2020;111(May):104916. doi:10.1016/j.oraloncology.2020.104916

2. $\quad$ Burket LW, Greenberg MS, Glick M, Ship JA. Text book of oral medicine. 11th ed. India: Thomson press; 2012. 
3. Bodhade AS, Dive AM. Chemoprevention of Premalignant and malignant lesions of Oral cavity- Recent Trends. Eur J Dent . 2013;7(2):246-50.

4. Rivera Cesar. Essentials of oral cancer. Int J Clin Exp Pathol. 2015;8(9):11884-11894. doi:10.5281/zenodo.192487

5. Mangalath U, Aslam SA, Hafiz A, et al. Recent trends in prevention of oral cancer. 2014;4(December):131138. doi:10.4103/2231-0762.149018

6. Manoharan S, Singh RB, Balakrishnan S. Chemopreventive Mechanisms of Natural products in Oral, Mammary and Skin Carcinogenesis: An Overview. Open Nutr J . 2009;2:52-63.

7. Danaraddi S, Koneru A, Hunasgi S, Ramalu S, Vanishree M. Natural ways to prevent and treat oral cancer. 2014;6(1). doi:10.4103/2249-4987.140213

8. $\quad$ Nussbaumer, S., Bonnabry, P., Veuthey, J. L., Fleury-Souverain, S. (2011). Analysis of anticancer drugs: a review. Talanta 85 (5), 2265-2289. doi: 10.1016/j.talanta.2011.08.034

9. $\quad$ Choudhari AS., Mandave PC., Deshpande M, Ranjekar P, Prakash O, Phytochemicals in Cancer Treatment: From Preclinical Studies to Clinical Practice, Frontiers in Pharmacology, (2020), 10:1614. (https://doi.org/10.3389/fphar.2019.01614)

10. Mokhtari RB, Homayouni TS, Baluch N, Morgatskaya E, Kumar S, Das B, et al. Combination therapy in combating cancer. Oncotarget. 2017;8(23):38022-43.

11. Mileo AM, Miccadei S. Polyphenols as modulator of oxidative stress in cancer disease: new therapeutic strategies. Oxidative Med Cell Longev. 2016;2016:6475624.

12. Mileo AM, Di Venere D, Mardente S, Miccadei S. Artichoke polyphenols sensitize human breast cancer cells to chemotherapeutic drugs via a ROS-mediated downregulation of flap endonuclease 1. 2020;2020.

13. Bhavana, S. M., \& Lakshmi, C. R. (2014). Oral oncoprevention by phytochemicals - a systematic review disclosing the therapeutic dilemma. Advanced pharmaceutical bulletin, 4(Suppl 1), 413-420.

14. Pandey G., Madhuri S. Medicinal plants: better remedy for neoplasm. Indian Drugs. 2006;43:869-874.

15. Cragg G.M., Newman D.J. Plants as a source of anti-cancer agents. J Ethnopharmacol. 2005;100:72-79.

16. Ramya N, Prakash R, Dhivya R. Anti cancer activity of Trachyspermum ammi against MCF- 7 cell lines mediates by p53 and Bcl-2 mRNA levels. 2017;6(2):78-83.

17. Bajpai VK, Agrawal P. Studies on Phytochemicals, Antioxidant, Free Radical Scavenging and Lipid Peroxidation Inhibitory effects of Trachyspermum ammi seeds. 2015;49(1). doi:10.5530/ijper.49.1.8

18. Hadi SM, Bhat SH, Azmi AS, Hanif S, Shamim U, Ullah MF. Oxidative breakage of cellular DNA by plant polyphenols: A putative mechanism for anticancer properties. 2007;17:370-376. doi:10.1016/j.semcancer.2007.04.002

19. Harborne JB. Phytochemical Methods A Guide To Modern Tecniques Of Plant Analysis, Third Edition. Chapman Hall. Published online 1998:58. doi:10.1017/CBO9781107415324.004

20. Wagner KH, Elmadfa I. Biological relevance of terpenoids: Overview focusing on mono-, di- and tetraterpenes. Ann Nutr Metab. 2003;47(3-4):95-106. doi:10.1159/000070030

21. Prieto P, Pineda M, Aguilar M. Spectrophotometric quantitation of antioxidant capacity through the formation of a .... Anal Biochem. 1999;269:337-341. doi:10.1037/a0037168

22. Mosmann T. Rapid colorimetric assay for cellular growth and survival: Application to proliferation and cytotoxicity assays. J Immunol Methods. 1983;65(1-2):55-63. doi:10.1016/0022-1759(83)90303-4

23. Hafer K, Iwamoto KS, Schiestl RH. Refinement of the dichlorofluorescein assay for flow cytometric measurement of reactive oxygen species in irradiated and bystander cell populations. Radiat Res. 2008;169(4):460-468. doi:10.1667/RR1212.1

24. Lakshmi S, Dhanya GS, Joy B, Padmaja G, Remani P. Inhibitory effect of an extract of Curcuma zedoariae on human cervical carcinoma cells. Med Chem Res. 2008;17(2-7):335-344. doi:10.1007/s00044-007-9069-9

25. Niehaus WG, Samuelsson B. Formation of Malonaldehyde from Phospholipid Arachidonate during Microsomal Lipid Peroxidation. Eur J Biochem. 1968;6(1):126-130. doi:10.1111/j.14321033.1968.tb00428.x

26. Kakkar P, Das B, Viswanathan PN. A modified spectrophotometric assay of superoxide dismutase. Indian J Biochem Biophys. 1984;21(2):130-132.

27. Sinha AK. Colorimetric assay of catalase. Anal Biochem. 1972;47(2):389-394. doi:10.1016/00032697(72)90132-7

28. Rotruck JT, Pope AL, Ganther HE, Swanson AB, Hafeman DG and Hoekstra WG. Selenium: biochemical role as a component of glutathione peroxidase. Science. 1973; 179: 588-590.

29. Ellman GL. Tissue sulfhydryl groups. Arch Biochem Biophys. 1959;82(1):70-77. doi:10.1016/00039861(59)90090-6 
30. B. Kumar, H. K. Sandhar, S. Prasher, P. Tiwari, M. Salhan, and P. Sharma, "A review of phytochemistry and pharmacology of flavonoids,” Internationale Pharmaceutica Sciencia, vol. 1, no. 1, pp. 25-41, 2011.

31. Aftab K, Atta-Ur-Rahman, K UsmanghaniBlood pressure lowering action of active principle from Trachyspermumammi (L.) spraguePhytomedicine, 2 (1995), pp. 35-40

32. Gibellini L, Pinti M, Nasi M, et al. Interfering with ROS Metabolism in Cancer Cells: The Potential Role of Quercetin. Published online 2010:1288-1311. doi:10.3390/cancers2021288 